\title{
MUDANÇA ESTRUTURAL DA ESFERA PÚBLICA
}

\author{
Felipe Mattei Martins ${ }^{1}$ \\ Artur José Renda Vitorino ${ }^{1}$ \\ Pontifícia Universidade Católica de Campinas (PUC), Campinas/SP - Brasil ${ }^{1}$
}

HABERMAS, Jürgen. Mudança estrutural da esfera pública. Tradução Denilson Luís Werle, 1. ed. São Paulo: Editora Unesp, 2014.

A referência etimológica de esfera pública formou-se na Alemanha na analogia entre público [öffentlich] e publicidade (publicité ou publicity), com determinações precisas e categorizadas como "público", "privado", "esfera pública" e "opinião pública". Na antiga cidade grega, a esfera pólis (cidade) era separada da esfera do oikos (casa) e não possuía um local específico, já que a esfera pública se dava pela léxis (diálogo). No século XVI, a palavra "privada" [privat] foi emprestada do latim privatus (private, em inglês e privé, em francês) e significa algo sem cargo público, ou exclusão da esfera estatal. Contudo, seus significados, aqui previamente apresentados, transformam-se no decorrer do tempo. Seus estudos mostram, assim, a evolução desses conceitos no decorrer da História.

$\mathrm{Na}$ Grécia antiga, o privado condizia à economia doméstica voltada para as necessidades pessoais, enquanto que o público se ajusta ao espaço de interação entre livres e iguais. Os cidadãos recebiam direitos e se reconheciam como iguais. Assim, era estabelecido o conceito de democracia para a época: a prática de fazer uso dos direitos dentro do espaço público. Na Grécia clássica, a liberdade não era exclusividade da vida pública, posto que no privado o espaço da liberdade estava longe da dominação e autoridades públicas. Existia uma separação nítida do que era público e do que era privado. Dando prosseguimento ao desenvolvimento das esferas, é desenvolvida uma análise sobre a esfera pública e privada no período medieval.

A Alta Idade Média, hierarquizada pelo clero, nobreza e servos também apresentava uma esfera pública que se subdividia em esfera pública representativa, que por sua vez era desdobrada em atributos (emblemas, armas); hábitos (vestimentas, penteado); gestos (modo de saudar, postura); e retórica (modo de falar, discursar). Os nobres consolidavam sua posição pelas virtudes exibidas: a esfera da comunicação política. Já a esfera pública literária se dava nas representações de teatro, na dança e nos torneios que aconteciam em 
praça pública e que, mais à frente, passavam a acontecer nos pátios e salões dos castelos. Nesse período, a administração pública era composta por um grupo de pessoas para discutir entre si questões da vida privada.

O privado deixa de estar restrito às questões econômicas e domésticas e amplia para as relações pessoais. Na Alta Idade Média, o clero mantém um local para discussões, a Igreja, onde a esfera pública era representada pelos rituais religiosos, liturgias, missas e procissões. Surge também o salão burguês, que nasceu da aristocracia para discussões de forma retórica e literária. Ao passar do tempo, essa esfera pública desdobrou-se em chás e cafés que eram ambientes instituídos pela elite para interagir entre si e com a nobreza, denominados como esfera pública literária. Esses ambientes não possuíam um caráter político, apesar de contextualizar a crítica como elemento dialético entre a nobreza e a elite, servindo também como crítica da arte.

A Revolução Francesa se mantinha no cunho literário, voltada para a crítica da arte. Os periódicos que surgiram em algumas partes da Europa entre o final do século XVII e o começo do XVIII também já tinham publicações com cunho literário e cultural, apesar de, aos poucos, trazerem informações da vida prática, política e social em geral. A esfera pública literária, então, iniciou um processo de reflexão crítica, a partir das informações trazidas nos periódicos, e adquiriu uma configuração de esfera pública politicamente ativa. Na Inglaterra, França e Alemanha, os ambientes como cafés cresceram fortemente e estavam vinculados aos periódicos que ali eram distribuídos. Os comentários políticos e sátiras faziam parte desses ambientes. A imprensa torna-se elemento fundamental na esfera pública, envolvendo críticas ao Parlamento e à Coroa. Nota-se que esses ambientes eram de sociabilidade e reflexão crítica.

No começo do capitalismo, tanto no norte da Itália como nos Países Baixos, em grandes feiras e cruzamentos de rotas marítimas, foi moldada uma nova ordem social. O comércio sai da organização fechada dos feudos e passa a se constituir nas cidades, as bases das operações. Assim como as mercadorias, as notícias também circularam em razão das distâncias geográficas, por exemplo, as cartas comerciais. O sistema de informação tinha como base jornais manuscritos e correspondências privadas, organizadas para o comércio. A imprensa se restringe às informações públicas, acessíveis ao público geral, momento em que a esfera pública era determinada pelo publicismo. O Estado passa a servir como Estado Fiscal, direcionado à administração pública. A imprensa passa a ser formada por jornais políticos que traziam informações sobre assembleias parlamentares, acontecimentos bélicos, rendimento de colheitas, impostos, transportes e comércio internacional. As notícias se transformaram em mercadorias, submetidas às leis de mercado.

A etimologia da palavra "público" começou a sofrer alterações em seu significado, cabendo, aqui, as especificidades de cada país. Na Alemanha, o público foi definido como uma multidão em torno de um orador ou ator em lugares públicos, público que lê e julga. $\mathrm{O}$ que é submetido à opinião, na França, torna-se publicité (publicidade).

A cultura se torna objeto de discussão e reúne um grupo de interlocutores como leitores, ouvintes e espectadores, formando-se como um porta-voz, um educador. Isso significa 
que a esfera pública literária não é mais como antes na burguesia, mas uma esfera pública política, mediando o Estado e as necessidades da sociedade. O povo não dispõe de conhecimento e de poder financeiro para participar desses grupos, até porque a massa é analfabeta (como no caso da Inglaterra, no século XVIII). A esfera pública é considerada como base para uma pedagogia, pois o emissor (no caso, orador ou porta-voz) traz, por meio do discurso, informações aos ouvintes e espectadores. O espaço público assume o papel de plataformas para discussão e transmissão de informações, disseminadas para a massa.

No final do século XVIII, o palco é estabelecido para o público leitor e espectador. Músicos se ocupavam das encomendas da Igreja para a composição estritamente funcional. As casas são construídas sob uma ótica da esfera pública. De modo diferente das casas burguesas, os cômodos são funcionais e muito pequenos, com exceção da sala que reúne os familiares e eventos sociais, fazendo do salão um espaço público. A família conjugal deixava de ser uma esfera privada para ser uma esfera humana. Surge a literatura para um público leitor amplo, que possibilitou aos homens a sua participação tanto na esfera pública como na privada.

As esferas estão presentes, ora em sua configuração privada, ora pública, dependendo das relações em que atuam. Ressalta-se que as mulheres ainda eram excluídas da esfera pública política. Os meios de comunicação modernos também sofreram influências de intelectuais quanto à cultura política e popular, formando entre eles uma nova organização. $\mathrm{O}$ que era publicado passa a ser controlado pelo Estado como uma verdadeira censura do que se pode ou não ser dito. Após a Revolução Francesa, esse fator de censura se acentua entre os jornais. A opinião pública assume um significado de juízo incerto, não totalmente demonstrado, ou seja, para que se faça valer, seria necessária uma prova da verdade. A opinião pública é denominada como reputação, que significa aquilo que se representa à opinião dos outros. A opinião pública passa a ser coletiva e indica um caráter social.

A imprensa se configura cada vez mais como mercadoria, apaga-se o limite entre a esfera pública e a privada. A esfera pública deixa de ser exclusiva do domínio da esfera privada. O comércio de jornais deixa de vender notícias e começa a redigir como uma opinião pública, obtendo eficácia política e, ainda mais, seguindo novamente com uma intenção pedagógica. Os editores, contratados com finalidade empregatícia, cedem às exigências dos seus superiores, os donos dos jornais, eruditos e escritores. A redação passa de literária para jornalística.

Não há como não notar a quantidade exorbitante de jornais, como no caso da França, que em tão pouco tempo surgiu no ano de 1789. A maioria dos periódicos e jornais tentava persuadir o público ou buscava uma intenção pedagógica. Em 1830, os anúncios já eram vistos nos jornais como espaços comercializados e muitas vezes permutáveis com as matérias desenvolvidas, elevando o interesse econômico da imprensa.

No século XX, com o surgimento de outros meios de transmissão de informações, como o telégrafo e o rádio, essas tecnologias contribuíram para organizar as informações. Em 1820, a propaganda, chamada inicialmente de "reclame" na França, inundou os veículos de comunicação para a divulgação de mercadorias. Porém, era a propaganda que mantinha o equilíbrio financeiro dos veículos de comunicação. Na medida em que as pro- 
pagandas aumentaram consideravelmente, o rádio possibilitou, ao público que não sabia ler, acesso às informações, antes restritas às pessoas letradas. Esse fato chama a atenção política, que procura produzir conteúdo publicístico associado aos interesses políticos.

As funções da esfera pública se misturam com os interesses privados, enquanto a pressão social exige uma resposta do Estado. Desse modo, a sociedade forma organizações privadas para reivindicar seus direitos e interesses. A complexidade das relações entre Estado e sociedade dá origem às federações, associações e sindicatos que intermedeiam a comunicação dos interesses de um para com o outro, num trajeto indireto de procedimentos institucionalizados da esfera pública política. Acontece que os partidos acabaram se tornando instrumentos de formação da vontade de quem compõe o partido e não das vontades do público, representando as organizações como deveria ser. Os meios de comunicação se tornam plataformas para as campanhas políticas publicitárias, fazendo dos partidos, ideologias de consumo.

\section{Dados dos aUtores:}

\section{Felipe Mattei Martins}

Doutorando no Programa de Pós-Graduação em Educação pela Pontifícia Universidade Católica de Campinas. Professor na Pontifícia Universidade Católica de Campinas, no Centro de Linguística e Comunicação, no Curso de Publicidade e Propaganda. Campinas/ SP - Brasil. felipe.mattei@hotmail.com

\section{Artur José Renda Vitorino}

Doutor em História pela Universidade Estadual de Campinas. Professor na Pontifícia Universidade Católica de Campinas, no Programa de Pós-Graduação em Educação e nas Faculdades de História e de Pedagogia. Campinas/SP - Brasil. arturvitorino@uol.com.br

Submetida em: 29-8-2018

Aceita em: 15-3-2019 